\title{
Realization of the Similarity Law in the Building Material Science
}

\section{LESOVIK VALERY STANISLAVOVICH ${ }^{1}$, TOLSTOY ALEKSANDR DMITRIEVICH ${ }^{1}$, GLAGOLEV EVGENIY SERGEEVICH ${ }^{1}$, AHMED ANEES AL-ANI ${ }^{1}$, AIMENOV ZHAMBUL TALHAEVICH ${ }^{2}$, SARSENBAYEV BAKYTZHAN KUDAIBERGENOVICH ${ }^{2 *}$ and SAUGANOVA GAUKHAR RAMZEYEVNA ${ }^{2}$}

\author{
'V.G. Shukhov Belgorod State Technological University, Belgorod, Russia. \\ ${ }^{2}$ M. Auezov South Kazakhstan State University, Shymkent, Kazakhstan. \\ *Corresponding author E-mail: Stroitelstvo_ukgu@ mail.ru
}

http://dx.doi.org/10.13005/ojc/350320

(Received: March 12, 2019; Accepted: May 06, 2019)

\begin{abstract}
The need for high quality of building products and structures determines the urgency of creating new ways to control the processes of forming the internal structure of modern composite building materials. This article discusses some aspects and problems on designing high-powder composites based on the law of similarity. The results showed that the determination of the compositions of these materisls and high adhesion property to each other and a low deformation characteristic. The results demonstrated that this less deformation characteristics is due to the similarity of the thermai expansion coefficients of the concrete components.
\end{abstract}

Keywords: Similarity law, High-performance materials, Powder concrete, Technogenic raw materials.

\section{INTRODUCTION}

For construction of buildings and installations having a special purpose and a complex design including unique ones, the application of a highstrength powder concrete is an actual task. The composition of such concrete differs from a traditional heavy concrete with raised cement content, finer sizes of particles a multicomponent structure, high dispersion of a filler ${ }^{1-3}$. Physicomechanical properties of the concrete depend on properties of its components. A role of each the component as well as their interaction mechanisms increases manyfold.
A theoretical basis for production of highquality composites is a new scientific transdisciplinary direction - geonics (geomimetics). This science uses results of studying natural processes and rocks for creation of building materials of the future ${ }^{4-6}$. It has allowed developing a system of designing a powder concrete taking into account the similarity law-manufacturing high-strength composites assumes the development of a designing system which permits to produce the composites in which all their components possess similar deformation characteristics, thermal expansion coefficients and have high adhesion.

This is an Open Access article licensed under a Creative Commons license: Attribution 4.0 International (CC- BY). Published by Oriental Scientific Publishing Company @ 2018 
For production of high-strength powder concretes scientists attach great importance to the choice and application of raw materials highly effective both from the point of view of practical logistics and their synergetic properties. The traditional raw materials applied now were studied and developed $30-50$ years ago for manufacture of composites with durability of 30-50 MPa and requirements to them were proper. For manufacturing composites of the new generation it is necessary to apply not only new kinds of raw materials, but also a new theoretical base. At the same time the complex use of mining wastes in the building industry has the certain specificity in respect of studying, assessment and determination of suitable reserves and also at blending transportation and synthesis of the composites ${ }^{7-11}$.

Criteria of applicability of the mineral components should include a quality, prevalence, availability, cost, constancy of a composition (Figure. 1).

Here it is necessary to use the "experience" of geological processes, for example high-strength siltstones; their strength and other properties are similar to powder concretes. To produce a strong and long-lived composite of a powder concrete it is necessary to provide reliable physicomechanical and operational characteristics of a material's structure taking into account energy indices of all components, and also the correspondence of other properties. This structure should have the similarity of its basic properties and genesis with natural materials.

Each property (or a number of properties) of the artificial stone material, produced at the hardening of rationally selected mixtures, is created by the complex interaction of the mixture's ingredients in certain time intervals. Powder concretes are complex polymineral compositions consisting of a considerable quantity of mineral components and new formations combined in a single whole.

The rational choice of ingredients of a mixed multicomponent fine-dispersed system guarantees the manufacturing a material with necessary operational characteristics. One of the main questions of this process is the careful selection of all "participants", their quantity and the nature of their similarity. Production of highstrength powder materials demands a theoretically substantiated approach to the development of concrete mixtures with a glance of chemical, mineralogical, granulometric and other properties of the raw components, and also their compatibility that will provide the desired result at all production stages: a dry powder mixture, a plastic water molding sand, a hardened stone with necessary strength.

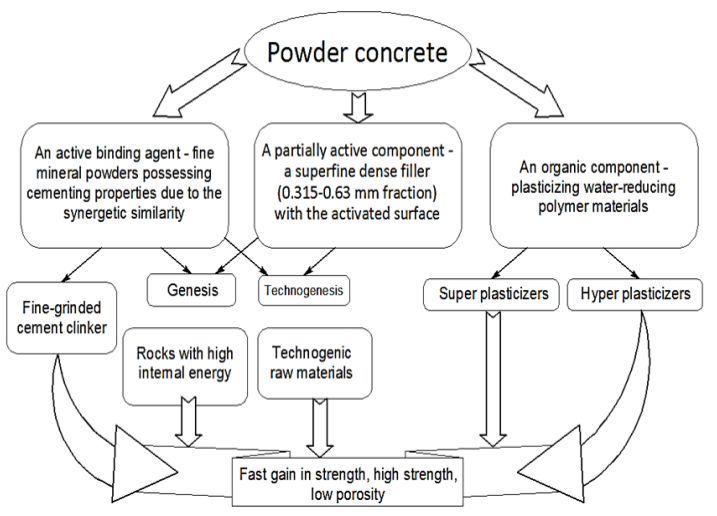

Fig. 1. The composites' synthesis algorithm

\section{MATERIALS AND METHODS}

During the experiments we applied the following mineral additives: aluminate and carbonatecontaining components; polymeric standard additives such as Melflux 2651, Melment; fine-grinded quartzitic sandstone - the accompanying rock mined at the Kursk magnetic anomaly. The quartzitic sandstone particles are characterised by a rough surface and the constant mineral composition including $\mathrm{SiO}_{2}$ (about $90 \%$ ), $\mathrm{Al}_{2} \mathrm{O}_{3}, \mathrm{Fe}_{2} \mathrm{O}_{3}, \mathrm{FeO}, \mathrm{MgO}, \mathrm{CaO}, \mathrm{TiO}_{2}$. The quartzitic sandstone has a crystal-granular structure from a fine-grained to aphanite one (Table 1).

Table 1: Physicomechanical properties of the quartzitic sandstone

\begin{tabular}{lc}
\hline Property & Index \\
\hline Real density, $\mathrm{kg} / \mathrm{m}^{3}$ & 2650 \\
Apparent density, $\mathrm{kg} / \mathrm{m}^{3}$ & 1300 \\
Voidage, \% & 50 \\
Porosity, \% & 0,81 \\
Compressive strength, MPa & \\
- in a dry state & 156 \\
- in a water-saturated state & 136 \\
- $\quad$ after 25 freezing-defrosting cycles & 126 \\
Softening coefficient & 0,97 \\
Water absorption, \% & 0,17 \\
\hline
\end{tabular}

There is no a unified approach to the experimental procedure of the high-strength materials production. Some researchers approach the problem from the point of view of technological 
mechanics. There are the approaches based on rheological properties of the system, the optimization of its granulometric composition, the interconnection between the optimum structure and extreme properties of the components (the I.A. Rybyev law'12). Basically the theoretical propositions and principles of development of fine-grained hardening systems (solutions and concretes) concern also the powder compositions though their synthesis, structure and properties considerably differ from usual concretes and solutions.

\section{RESULTS}

The application of the complex organicmineral additives and various binding agents, containing technogenic raw materials in the combination with super and hyper fluidifiers as a siliceous component, is a basis of perspective concrete technologies.

The suggested control methods of the structure formation of hardening powder mixtures with technogenic components allow producing the composites with strength of 80-100 MPa (Table 2).

Table 2: Comparative indicators of properties of normal and powder concretes

\begin{tabular}{lcc}
\hline Index & \multicolumn{2}{c}{ Value } \\
& $\begin{array}{l}\text { Common } \\
\text { concrete }\end{array}$ & $\begin{array}{c}\text { Powder } \\
\text { concrete }\end{array}$ \\
\hline Average density, kg/m ${ }^{3}$ & $2200-2500$ & 2300 \\
Compression strength, MPa & Oct-50 & 97,5 \\
Water retentivity, \% & $78-80$ & 90 \\
Constructive quality coefficient & 0,17 & 0,36 \\
Water tightness grade, W & $4-F e b$ & 4 \\
Frost resistance degree, F & $50-150$ & 300 \\
Abradability, kg/m² & $0,7-0,8$ & 0,36 \\
Shrinkage & Cracks are absent \\
Heat conductivity coefficient, & $0,8-1,2$ & 1,29 \\
W/m.K & & \\
\hline
\end{tabular}

The carried out experiments permitted to establish the acceleration of hydrate formation processes in the polymineral hardening system containing the components selected in accordance with the similarity law that guarantees the production of the material with desired service properties. The data of X-ray phase and differential thermal analyses show the considerably greater occurrence of new formations in the structure; the reflections in the roentgenograms and the mass loss in the derivatograms (Fig. 2) prove that. The possibilities to accelerate the hydration in the complex powder systems increase also owing to the application of technogenic mineral substances. In this case the multicomponent composition, polymineral structure and high specific surface change the processes of new formations' synthesis at the expense of genesis and technogenesis of the raw materials. The presence of active silica and carbonates, which react with aluminate phases of a cement clinker forming calcium hydrocarboaluminate crystals, leads to the acceleration of the hardening the cement stone and to increase of final strength of the material. Then, as a result of the ongoing hydration there is formation of parts of a new type system at the expense of crystallisation growth of pico-, nano- and micro dimensional high-base calcium hydrosilicates depending on genetic features of the initial rock. The subsequent crystallisation of previously formed phases leads to the self-consolidation of different parts of the system and their further self-organization running according to the nature-like mechanism; it provides high final strength and water resistance of the material. This hydration mechanism promotes the formation of a high-strength composite structure with minimum internal stresses and volume deformations that considerably reduces the micro crack formation.

Thus, the theoretical approaches to the development and manufacture of traditional concretes are not always applicable to high-strength multicomponent powder concretes neither on their composition nor on operation loads. The selection technique of the composite's components taking into account the similarity law of all its ingredients can be applied as a basis for the development of the necessary approach.

The consolidation and strengthening of the structure is caused by the growth of the crystal phase and replacement of water contacts between separate phases of new formations by it (Figure 3).

A hard carcass for all the powder concrete samples consists of the separate particles of technogenic origin components with various specific surfaces and strongly pronounced contact zones of new formations. At the magnification it can be seen that these particles are almost completely covered 
with the hydration products as the technogenic grains are a substrate for forming the new formations; the consequence of that is the large quantity of globules intergrown with their surface (Figure 3).
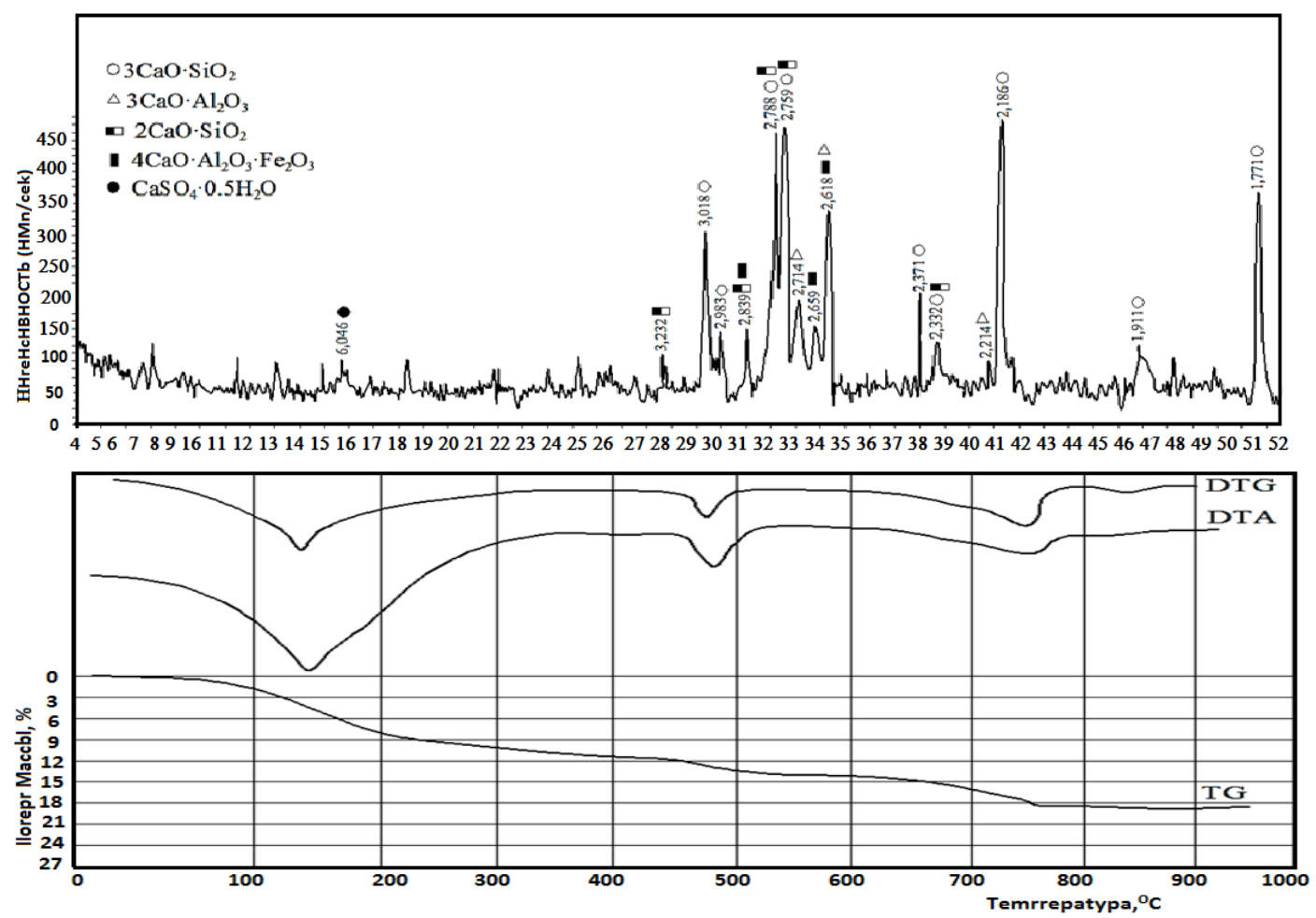

Fig. 2. Phase characteristics of multicomponent powder systems

In addition, the silica micro particles contained in the composition are the hydration activators, and the coarser particles of powder binding agent act as a micro filler and ipso facto reduce the possibility of shrinkage deformations and improve operational characteristics of the composite.

The waste product of ferrosilicon manufacture (micro silica), aluminate-containing additives, the wastes formed at crushing of quartzitic sandstone allow to improve considerably the main technical and operational properties of concretes and building products not reducing their constructive hardness, stability and operating life. The given purpose has been reached by means of the consolidation of the structure, reduction of pores and micro cracks.

The acceleration of the interaction reaction is caused by the high dispersion of the components, which compact the system filling the cavities with the strong hydration products and improving adhesion with the fillers.
The structure of the high-strength powder concrete with the optimum composition produced at the joint grinding of the mineral components with the plasticizing additive is homogeneous (Figure 4). The specific character of the structure leads to the active growth of new formations at the expense of addition of the water, contained in the nano- and micro porous composites, and appreciably promotes the synthesis of the contact zones' microstructure and all the stone in whole. The ultimate compression strength of the composite makes $95 \mathrm{MPa}$; this value is more than the strength of a common concrete in two times. It is confirmed by the results of many physicomechanical tests.

Figure 3 represents the dense structure of the powder concrete, which is characterised by practically total absence of pores and micro cracks. It was produced due to the well-selected composition, addition of the correct quantity of fine-dispersed technogenic components, their closest packing and the self-compensating hardening effect. 


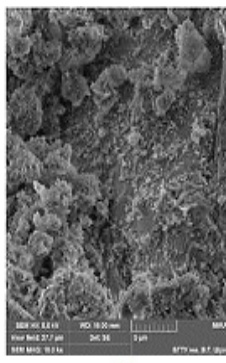

a

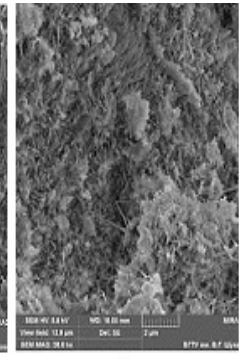

b

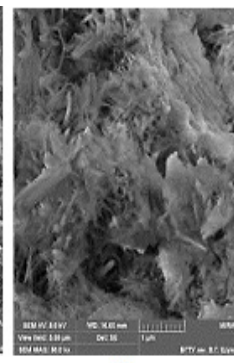

c
Fig. 3. A microphotograph of the powder concrete-based

During the hardening period the material's density was increasing. It promoted the obtaining of the high-strength concrete with high physicomechanical and operational characteristics. At the end of the hardening period, at the moment when the artificial stone reached its highest density, and, therefore, its best dynamic characteristics, the active binding process of portlandite came to the end. The high density of the powder concrete with the fine-dispersed filler after 28 days of hardening is a consequence of the high structural order of the granular material.

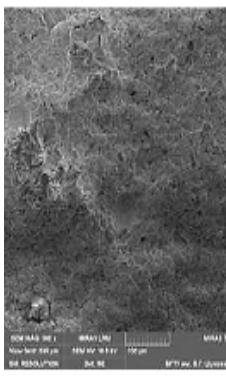

a

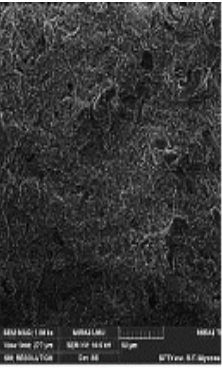

b

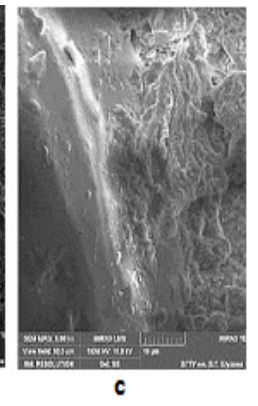

Fig. 4. A microstructure of the high-strength powder concrete on the basis of the fine-grinded quartzitic sandstone
Studying the microphotos of the hardening compositions has shown the following:

- The microstructure of the cement stone, produced at the joint grinding is more homogeneous than at the separate grinding of the components;

The cement stone's microstructure contains the needle crystals penetrating the stone's volume;

- $\quad$ The presence of dense new formations near the grains of the filler.

After termination of the standard hardening term the microstructure of the powder concrete is characterized by the structural order and raised density (Figure 3).

\section{ACKNOWLEDGEMENT}

Thus, the application of theoretical propositions of geonics (geomimetics), in particular, the similarity law, allows to produce the high-strength powder concretes in which all ingredients have high adhesion and similar deformation and temperature characteristics. The first approbation of this law has allowed us to obtain the composites based on the technogenic raw materials with the ultimate compression strength of $100 \mathrm{MPa}$.

The work is realized in the framework of the RFBR according to the research project No 18-29-24113; The work is realized in the framework of the RFBR according to the research project No 18-03-00352.

\section{REFERENCES}

1. Bazhenov lu.M., Demianova V.S., Kalashnikov V.I. Modifitcirovannye vysokoprochnye betony [Modified high-performance concretes].Moscow: ASV., 2007, 368.

2. Tolstoy, A.D., Lesovik, V.S., Kovaleva, I.A. Highstrength decorative complexes with organomineral additives - Advances in Environmental Biology., 2014, 8(13), 145-149.

3. Lesovik, V.S., Zagorodnyuk, L.K., Mestnikov, A.E., Kudinova, A.I., Sumskoi, D.A. Designing of mortar compositions on the basis of dry mixes. International Journal of Applied Engineering Research., 2015, 10(5), Pages
12383-12390.

4. Lesovik V.S. Geonika (Geomimetika) [Geonics (Geomimetics)]. Primery realizatcii v stroitelnom materialovedenii [Examples of application in building materials science]. Belgorod: Bulletin of BSTU named after V.G. Shoukhov., 2014, 206.

5. Lesovik V.S., Zagorodniuk L.Kh., Chulkova I.L. Zakon srodstva struktur v materialovedenii [Law of similarity of structures in materials science]// Fundamentalnye issledovaniia [Fundamental research]., 2014, 3(2), 267-271. 
6. Bazhenov, Y.M., Zagorodnjuk, L.H., Lesovik, V.S., Yerofeyeva, I.V., Chernysheva, N.V., Sumskoy, D.A., Concerning the role of mineral additives in composite binder content. International Journal of Pharmacy and Technology., 2016, 8(4), 22649-22661.

7. Tolstoi A.D., Lesovik V.S., Kovaleva I.A., Organomineralnye vysokoprochnye dekorativnye kompozitcii [Organic and mineral high-performance decorative compositions]. Bulletin of BSTU named after V.G. Shoukhov., 2014, 5, 67-69.

8. Lesovik, B.C., Kontceptciia imetodologiia otcenki syria stroiindustrii [Concepth and methodology of evaluating raw materials for the building industry] / V.S. Lesovik. Problemy stroitelnogo materialovedeniia i novye tekhnologii: sb. dokl. mezhdunar. konf. [lssues of building materials science and new technologies: proceedings of the international conference] - Belgorod: BelGTASM., 1997, 5, 24-29.

9. Sarsenbayev N.B., Sarsenbayev B.K., Aubakirova T.S., Aimenov J.T., Abdiramanova K.S. Phase composition and structureformation of the low-clinkered floured cements // Eurasian Chemico-Technological Journal., 2014, 16(4), 333-338.
10. Aymenov Zh.T., Sarsenbayev B.K., Sarsenbayev N.B., Aldiyarov Zh.A. Use of soiar energy for heliotherm treatment of concretes on the basis of alkali cements $115^{\text {th }}$ Asian Regional Conference on Soil Mechanics and Geotechnical Engineering, ARC 2015, Fukuoka International Congress CenterFukuoka, Kyushu, Japan, Nov 9-13, 2015//15 th Asian Regional Conference on Soil Mechanics and Geotechnical Engineering, ARC 2015: New Innovationsand Sustainability., 2015, 2742-2746.

11. Aymenov A.Zh., Sarsenbayev N.B., Khudyakova T.M., Sarsenbayev B.K., Batyrkhanov A.T., Kopzhassarov B.T., Effect of additive of polymetallic ores' tailings on properties of composite cements //Eurasian Chemico-Technological Journal., 2016, 18(2), 153-160.

12. Rybev, I.A., Otkrytie zakona stvora i vzaimosviaz ego $s$ zakonom kongruentcii $v$ stroitelnom materialovedenii [Discovering the gauging law and its relation to the law of congruence in building materials science]. Stroitelnye materialy [Building materials]., 1999, 12, 30-31. 